\title{
The Role of Mobile Technology in Overcoming Women's Entrepreneurship Barriers in Morocco
}

\author{
Yassine El Haloui*, Bouchra Alj and Youssef Jamal \\ University of Hassan II, Casablanca, Morocco; yassine-elhaloui@hotmail.fr, aljbouchra@yahoo.fr, \\ prof.youssefamal@gmail.com
}

\begin{abstract}
Background/Objectives: The aim of this study is to shed light on the constraints undermining women's participation in entrepreneurship activities and how mobile technology can help overcome these barriers. Methods/Statistical Analysis: To measure the women's participation in the economy, we analyzed statistics from Moroccan official sources and international ones. Also, we based our work on a literature review to address the influence of mobile technology on women's entrepreneurship. Findings: Our findings suggest that women entrepreneurs in MENA zone are facing family constraints, inferior level of education compared to men, low financial inclusion and limited mobility allowance. In many developing countries, mobile technology is showing its ability and potential to overtake women's entrepreneurship constraints. Improvements/Applications: To fully understand the connection between women's entrepreneurship potential and mobile technology it's important to conduct longitudinal studies.
\end{abstract}

Keywords: Entrepreneurship Barriers, Mobile Technology, Women Entrepreneurship, Women's Entrepreneurship Participation

\section{Introduction}

Since late 1990s, Morocco has conducted numerous initiatives and strategies to improve its economic performances and the social development of its population. However, despite a constant economic growth, Morocco is still suffering from important inequalities. There is a weak participation of young people and women in the economic activity. Only $25.57 \%$ of women are effectively active. In some developing countries, women rounds unemployment by turning to entrepreneurship. Morocco, $21.5 \%$ of the LLCs were created by women in 2016 versus $78.5 \%$ by men ${ }^{1}$ we are examining the reasons for this important gender gap in entrepreneurship. The first section presents the statistics about Moroccan women's participation in the economy and in entrepreneurship.

The second section covers the main barriers of women entrepreneurship in developing countries and in Morocco in particular. The third section addresses the contribution of mobile technology in surpassing women's entrepreneurship constraints.

\section{Methodology}

As we presented in the introduction, the first section concerns the statistics and data about Moroccan women's participation in the economy. To this end, we based our analyses on the reports of national institutions like Le Haut Commissariat au Plan (HCP) which is a principal economic and social statistics supplier in Morocco and also an independent one. In the international level, we referred to the contributions of The World Bank, The Global Entrepreneurship Research Association and other institutions. In order to present the second section which is linked to the women's entrepreneurship barriers in developing countries and Morocco in particular, we conducted a literature review in order to identify the principal constraints that stops women from achieving their economic potential and which are shared by the different authors. In the third section which addresses the role of mobile technology in overcoming women entrepreneurship barriers, we present the different private initiatives like mobile applications that help women in 
Asia and Africa to surpass their entrepreneurship potential.

\section{Section 1: Statistics and Data about Women Entrepreneurship in Morocco}

The structural Reforms conducted by Morocco in late nineties improved the economy significantly with a constant economic growth and ameliorations in the social welfare. However, the weak participation of Moroccan women in the economic activity is an eye catching fact. The activity level of women is $25,57 \%$ compared to 70 , $42 \%$ for their male counterpart in 2017 and just $13 \%$ in urban areas $\underline{2}$ as shown in Table 1.

Table 1. Activity level in Morocco (HCP, OIT)

\begin{tabular}{|l|l|l|l|}
\hline & $\mathbf{2 0 1 5}$ & $\mathbf{2 0 1 6}$ & $\mathbf{2 0 1 7}$ \\
\hline $\begin{array}{l}\text { Total Activity } \\
\text { Level }\end{array}$ & $49,21 \%$ & $49,34 \%$ & $49,46 \%$ \\
\hline $\begin{array}{l}\text { Men Activity } \\
\text { Level }\end{array}$ & $70,49 \%$ & $70,46 \%$ & $70,42 \%$ \\
\hline $\begin{array}{l}\text { Women } \\
\text { Activity Level }\end{array}$ & $25,33 \%$ & $25,46 \%$ & $25,57 \%$ \\
\hline
\end{tabular}

Concerning the $25,57 \%$ of women who are active, $19 \%$ are working in the informal sector ${ }^{3}$. This situation doesn't improve which is seriously undermining the wellbeing of the Moroccan economy ${ }^{4}$. Compared to other countries, Morocco is slightly above the MENA zone average ( $21,8 \%$ of women are active) but very far from a number of developing countries with $45 \%$ of effectively active women. Morocco is part of the $20 \%$ of countries with the least women participation in the economy.

The gender gap in Morocco is also predominant in entrepreneurship activity. At the national level, Morocco is ranked in the $70^{\text {th }}$ place by The Global Entrepreneurship and Development Index, 2017 which is positioning the country in the $11^{\text {th }}$ place in the MENA zone out performed by Lebanon ( $63^{\text {rd }}$ place globally). Using data from Moroccan institutions (HCP and OMPIC) and international ranking (Gender Global Entrepreneurship and Development-2014) stresses that only 21,5\% of Moroccan Low Liability Companies were created in 2016 by women versus $78,5 \%$ by men.

Considering the statistics presented above, we can say that there is an important shortfall caused by the weak participation of women in the Moroccan econ- omy. Economically, this situation is causing a loss in the national revenue and the economic growth. Socially, depriving women from earning financial resources is impacting negatively their empowerment and the welfare of their whole family $y^{5-7}$.

It is indispensable for all parties to join forces in order to overcome this situation. But before trying to address solutions, based on our literature review, section 2 presents the main constraints faced by women in terms of entrepreneurship participation.

\section{Section 2: Barriers to Women \\ Entrepreneurship}

In $\frac{8.9}{}$ terms of economic participation, The Middle East and North Africa are the most affected regions by the loss of income due to the gender gap. The literature review that we selected shows that women's entrepreneurship is suffering from four principal constraints: cultural and social limitations, lack of business skills and education, shortness of access to finance and capital and also an inadequacy of State initiatives and support.

As cited above, women in MENA zone are experiencing more barriers in terms of entrepreneurship participation. In ${ }^{10}$ many Arab countries, the cultural state of mind says that women have to take in charge family obligations as cooking, raising kids and housekeeping and have no role in earning revenue. It is the man who is responsible for providing financial resources to the family. Also, the religious and cultural beliefs indicate that women don't have to go out travel or meet other men without the presence and permission of their father or husband. These restrictions are creating a disorder among men and women in the household and prevent women from their empowerment.

Without a certain freedom of movement, networking and a lowered family's obligations, it is clear that women can't start and conduct a business.

The second constraint that we considered is the lack of business skills and education. This barrier could be a result of the first. Cultural and social pressures limit the number of girls schooling years.

Also, in the majority of Arab countries, parents are according less attention to the education of their daughters compared to their sons, expecting them to be good future wives and mothers. Without an appropriate formal education and experience, women can't have access to business skills like analyzing the economic environment, managing resources and communicate effectively. 
The lack of access to capital and finance is the third constraint that we collected. Stoilkovic $\underline{8}$ insists that without access to finance it is almost impossible for a business to succeed. She points out the fact that $70 \%$ of women owned SMEs in developing countries don't have access to finance. This situation is accentuated by the low women's financial inclusion1. In Morocco, 37\% of women have a bank account and $77 \%$ for $m^{11}$. One of the principal reasons for this gender gap in account ownership is the social pressure. Women in developing countries are also suffering from discrimination in loans acceptance and are asked to bring more guarantees ${ }^{12}$. The result is that they turn to informal financial resources by borrowing from family and friends who are male dominated.

The fourth and last barrier to women entrepreneurship that we selected is the inadequacy of State initiatives and support. Morocco has launched in 2006 an initiative called Moukawalati which aimed to promote small enterprises creation and development. However, there was no significant initiative those considerate women's entrepreneurship specifications and constraints. It is very important to implement adapted and innovative solutions to help women manage all the challenges that they face in terms of business creation and management.

\section{Section 3: The role of mobile technology in overcoming women entrepreneurship constraints}

Pastdecadesshowed that Informationand Communication Technologies (ITC) are effective in improving people's lives. Mobile technology in particular is helping people connect with each other and with their environment. In $\frac{13}{3}$ the business area, mobile technology reduces travel costs and effort, permits to have information effectively and accessing to finance with fewer constraints.

In this section, we investigate the role of mobile technology in surpassing a part of women's entrepreneurship barriers. We chose this way regarding mobile technology's penetration in Morocco and its development potential.

Thus, according to the ANRT (Agence Nationale de Réglementation des Télécommunications) annual report of 2017 about the usage of ICTs in Morocco, 95\% of the population has access to mobile phones in urban area and $90.7 \%$ in rural places. $63.1 \%$ of men have access to internet versus $53.5 \%$ for women. Concerning smart phones, $69.5 \%$ of men and $64.5 \%$ women are equipped. $90 \%$ of internet users are using their devices to access social media web sites and applications ${ }^{14}$.

After presenting the importance of mobile technology and mobile internet penetration in Morocco, we are going to address the impact of mobile technology on lowering women's entrepreneurship obstacles.

As we indicated above, women in Morocco and other developing countries are suffering from movement and traveling limitations. In the business sphere, mobile technology can be effective in allowing them to get market information's like row materials availability and prices, setting product's prices and avoiding middle men $\frac{15}{}$. Mobiles can also connect women entrepreneurs with their potential customers with a minimum of effort and without travelling villages is a mobile application launched in Asian countries. It connects farmers with their potential clients and agricultural experts, accessing to market prices and providing them with targeted mobile advertising.

$\mathrm{In}^{\frac{16}{6}} \mathrm{M}$-Farm is a platform that enables its users to benefit from a virtual marketplace. It gives farmers important advices about how to plant and presents practices to improve their productivity. $\operatorname{In}^{16}$ collaborated with Vodafone to conduct a survey about the importance of mobile technology in improving Ghanaian micro-businesses. The results showed that a majority of respondents use mobile internet to track prices, get business ideas, search for business information's and develop their business skills. Social media web sites and applications are also very effective. Generally, mobile technology permits women to gain more autonomy and empowerment.

Low formal education and a lack of business skills is one of the main obstacles that face women entrepreneurs. Mobile internet can be a powerful tool to overcome this situation. There are a lot of online courses, interviews and reports that can help women improve their business skills and communication level. Smart woman is a women only mobile application launched in Qatar by Ooredoo and Qualcomm Wireless Reach ${ }^{17}$ which is available in many Arab countries. It provides its users with business contents, a virtual networking space and advices from business mentors. The third barrier for women's entrepreneurship that we identified is the lack of access to finance. The gender gap in banking access and finance has multiple reasons. Mobile banking can help reduce the severity of this situation. Using their phones, women can send and receive payments, manage their finances and pay their 
bills without traveling to a bank branch. This possibility has the advantage to be more cost effective, avoiding banking constraints and engaging women in long journeys.

Mobile money solutions empower women in many developing countries. Hapinoy Mobile Money Hub Program was launched in 2014 by Hapinoy, Qualcomm Wireless Reach, Smart Money, and MasterCard in order to propose mobile money services to Thai women in underserved areas. It permitted them to have access to financial services and increase their revenues by becoming mobile money agents. Adopting mobile money services can be a stepping stone for women to secure formal loans in the future. Using mobile money permits women to have a record that can help financial institutions to evaluate the risk of lending them money $\frac{18,19}{\underline{1}}$.

The fourth and last constraint to women's entrepreneurship that we selected is State initiative and support adapted to women. The Gender Global Entrepreneurship and Development Index of 2014 points out the fact that Morocco has not implemented specific measures to improve women's entrepreneurship. It is indispensable to identify a framework to overcome this situation. The Moroccan government has to identify the appropriate strategy to help women entrepreneurs achieve their full potential.

\section{Conclusion}

Analyzing data about Moroccan women entrepreneurship allowed us to realize that there is an important gender gap in terms of economic participation. The literature review that we conducted shows that women in Morocco and in other developing countries are suffering from four main barriers which are social and family constraints, lack of formal education and business skills, limited access to finance and maladjusted state initiatives. Considering these barriers, our findings suggest that mobile technology can be effective in overcoming women entrepreneurship constraints.

Mobile applications launched in many countries proved its effectiveness in improving women's entrepreneur's business skills and communication. Also, it helped to connect with customers and suppliers without traveling or engaging costly and insecure journeys. Moreover, mobile money helps women accessing to financial services at a lower cost and allows them to avoid formal finance constraints. It is obvious that all parties should join their forces to improve women entrepreneurship in developing countries. However, it is indispensable for the government to implement well designed programs and strategies to improve women's economic participation. As a conclusion, all stakeholders should remember that investing in women's development means improving the welfare of the whole nation.

\section{References}

1. Meunier F, Krylova Y, Ramalho R. Women's Entrepreneurship: How to Measure the Gap between New Female and Male Entrepreneurs. Policy research working paper No. 8242. World Bank. 2017; 1-28. https://doi. org/10.1596/1813-9450-8242.

2. Global entrepreneurship Monitor [internet]. https://www. gemconsortium.org/report/gem-2017-2018-global-report. Date accessed: 30/01/2018.

3. Haut-Commissariat au Plan. La femme Marocaine en chiffres: Evolution des caractéristiques démographiques et socioprofessionnelles. 2018; 1-134.

4. Chauffour JP. Le Maroc à l'horizon 2040. Groupe de la Banque Mondiale. 2018; 1-405.

5. Zoltan JA, Szerb L, Lloyd A. The Global Entrepreneurship and Development Index. Springer Briefs in Economics. 2017; 11-27.

6. Minniti M, Naudé W. What Do We Know About The Patterns and Determinants of Female Entrepreneurship Across Countries? Eur. J. Dev. Res. 2010; 22(3): 277-293. https://doi.org/10.1057/ejdr.2010.17.

7. GSMA Development Fund. Women and mobile: A global opportunity. 2017; 1-57.

8. Iqbal S, Islam A, Ramalho R, Sakhonchik A. Unequal before the Law: Measuring Legal Gender Disparities across the World. Policy research working paper series 7803 . World Bank. 2016; 1-53. https://doi.org/10.1596/1813-9450-7803.

9. West DM. How Mobile Technology is Driving Global Entrepreneurship. Governance Studies at Brookings 2012; 1-11.

10. Zeidan S, Bahrami S. Women Entrepreneurship in GCC: a Framework to Address Challenges and Promote Participation in a Regional Context. Int. j. bus. soc. sci. res. 2014; 2(14): 100-107.

11. Bank Al-Maghrib. Rapport annuel sur la supervision bancaire. Banque Centrale de Tunisie. 2017; 1-77.

12. Cetindamar D, Gupta VK, Karadeniz EE, Egrican N. What the numbers tell: The impact of human, family and financial capital on women and men's entry into entrepreneurship in Turkey? Entrepreneurship \& Regional Development. 2012; 
24(1-2): 29-51. https://doi.org/10.1080/08985626.2012.637 348.

13. Nisreen A, Willis R. The use of mobile phones to support women's entrepreneurship in the Arab countries. International Journal of Gender and Entrepreneurship. 2016; 8(4): 424-445. https://doi.org/10.1108/IJGE-102015-0037.

14. Agence Nationale de Réglementation des Télécommunications. Rapport annuel. 2017; 1-34.

15. Donner J, Escobari MX. A review of evidence on mobile use by micro and small enterprises in developing countries. J. Int Dev. 2010; 22(5): 641-658. https://doi.org/10.1002/jid.1717.

16. Boateng R. Mobile phones and micro-trading activities - conceptualizing the link. Emerald Group
Publishing Limited. 2011; 13(5): 48-62. https://doi. org/10.1108/14636691111160635.

17. Happy women's entrepreneurship day [internet]. https://www.indiaretailing.com/2016/11/19/ technology/10-women-entrepreneurs-who-matter-inindian-e-commerce/. Date accessed: 19/11/2016.

18. Small Enterprises Research and Development Foundation [internet]. http://serdef.org/about-us/. Date accessed: 2017.

19. Zoltan JA, Desai S, Hessels J. Entrepreneurship, economic development and institutions. Small Business and Economics. 2018; 31(3): 219-234. https://doi.org/10.1007/ s11187-008-9135-9. 